\title{
Varietal Differences in Tomato Intumescence under Changing Water Conditions
}

\author{
Yoko MIYAMA $^{1}$ and Nanako YASUI ${ }^{2}$ \\ ${ }^{1}$ Department of Agriculture, Fukushima University, 1-Kanayagawa, Fukushima 960-1296, Japan \\ ${ }^{2}$ Kanagawa Agricultural Technology Center, 1617-Kamikisawa, Hiratsuka, Kanagawa 259-1204, Japan
}

(Received December 16, 2020; Accepted March 6, 2021)

\begin{abstract}
Tomato (Solanum lycopersicum L.) intumescence severely affects tomato plants and thereby crop yields. In this study, we investigated the differences in intumescence between varieties. We assessed the shoot:root (S/R) ratio and incidence of intumescence in seedlings of 12 tomato varieties subjected to sudden increases in ambient humidity and soil moisture. The $\mathrm{S} / \mathrm{R}$ ratio and severity of intumescence injury were positively correlated. Next, three tomato varieties with different $\mathrm{S} / \mathrm{R}$ ratios and intumescence incidence were assessed. Changes in xylem pressure potential of seedlings occurred in response to a changing water environment in a controlled environment chamber, i.e., from a dry condition ( $50 \%$ relative humidity, no irrigation) to a wet condition ( $90 \%$ relative humidity, sub-irrigation). The xylem pressure potential decreased under dry conditions in relation to the $\mathrm{S} / \mathrm{R}$ ratio and intumescence incidence but increased rapidly after exposure to wet conditions. Tomato varieties with large $S / R$ ratios showed large changes in their water potential in response to changes in the surrounding water environment, and it is thought that cells are more likely to rupture when water potential increases after a transition from dry to wet conditions.
\end{abstract}

Keywords : shoot:root ratio, soil moisture, water potential, xylem pressure potential

\section{INTRODUCTION}

Damage caused by intumescence has recently become a serious issue in tomato-producing areas (Wu et al., 2017; Misu et al., 2018). Intumescence is a physiological disorder and non-pathogenic disease that occurs in many plant species (Eguchi et al., 2016). These species include members of the Solanaceae family, such as the eggplant (Solanum melongena) (Eisa and Dobrenz, 1971), potato (Solanum tuberosum L.) (Petitte and Ormrod, 1986), and tomato (Solanum lycopersicum L.) (Lang et al., 1983).

In tomato, intumescence causes abnormal outgrowths of the leaf epidermal and palisade parenchyma cell walls, and of the petiole or stem surfaces during early seedling growth or during cultivation after transplanting under greenhouse conditions. Blisters occur on the leaf abaxial surfaces in mild cases of intumescence (Fig. 1A, B), deformities of compound leaves can develop as the condition worsens (Fig. 1C, D), browning and necrosis appear in more severe cases, and leaf abscission occurs in extreme cases, resulting in a significant decrease in growth.

It has been reported that there are differences between varieties in the occurrence of tomato intumescence (Ozawa et al., 2018). However, it is not clear why there are differences between varieties. Although intumescence reportedly results from cell hypertrophy and rupture (Balge et al., 1969; Eisa and Dobrenz, 1971; Lang and Tibbitts, 1983; Lang et al., 1983; Wetzstein and Frett, 1984; Pinkard et al., 2006; Craver et al., 2014; Suzuki et al., 2020), the underly- ing causes are not yet fully understood. Previous studies have indicated that a high relative humidity, high root medium water content, or a combination thereof are the causes of intumescence (Metwally et al., 1970; Eisa and Dobrenz, 1971; Misu et al., 2018). These reports have suggested that excess turgor pressure may be the primary cause of intumescence. Since intumescence involves the swelling and rupture of cell walls, it is likely that sudden variations in the plant water potential will influence the onset of intumescence. Plant water potential has been shown to be closely related to the water environment (Kramer and Boyer, 1995). For example, the water potential of tomato plants has been shown to be affected by the relative humidity and soil moisture content when grown in controlled climate chambers (Araki, 1993), and by attributes of the water environment, including weather and soil water suction pressure ( $\mathrm{pF}$ value), during cultivation under field conditions (Fusao, 2003). Furthermore, the water potential of tomato plants is affected by water absorption and transpiration rates, as influenced by atmospheric and soil water potentials (Zhang et al., 2017). Lang and Tibbitts (1983), however, reported no differences in intumescence incidence at relative humidity levels of $30 \%, 80 \%$, and $92 \%$. Considering these findings, we proposed that intumescence does not occur merely owing to the persistence of high levels of humidity and soil moisture content, but rather because of a sudden fluctuation of these ambient variables from low to high levels.

Tomato varieties exhibit different responses in water potential to changes in the water environment (Torrecillas

Corresponding author: Yoko Miyama, fax: +81-24-503-4990, e-mail : y_miyama@agri.fukushima-u.ac.jp 


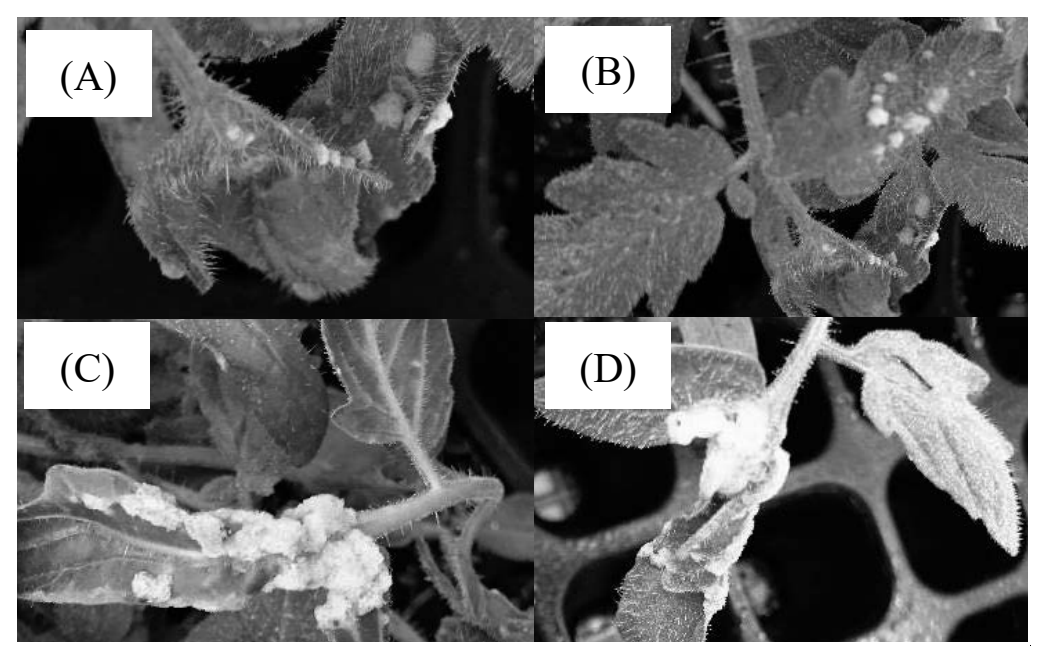

Fig. 1 Damage to tomato plants caused by intumescence. (A) and (B) show mild damage with blisters on the leaves. (C) and (D) show moderate damage with deformed compound leaves.

et al., 1995; Rahman et al., 1998, 1999; Moles et al., 2018), e.g., atmospheric and soil water potential fluctuations. Collectively, these studies suggest that differences in intumescence incidence among varieties may be linked to variations in their water potentials. In addition, plant water potential is influenced by water absorption and transpiration rates (Zhang et al., 2017). Thus, intumescence onset may be affected by the balance between the root water-absorption rate and leaf transpiration rate. The observed differences in intumescence incidence among tomato varieties may, therefore, be explained by differences in their root water-absorption rate to leaf transpiration rate ratios. Assuming that no significant differences among varieties were present in terms of the water transpired per unit shoot weight, or in the rate of water absorption per unit root volume, the varieties that show large $S / R$ ratios will presumably experience a greater water deficit under dry conditions than varieties with lower $S / R$ ratios. In other words, it is possible that varieties with a higher $\mathrm{S} / \mathrm{R}$ ratio are more likely to develop blistering.

The present study aimed to examine the relationship between the changes in seedling water potential and the differences in intumescence rates among tomato varieties under changing water conditions. Tomato varieties grown in a closed seedling production system were placed in a controlled-environment chamber and the effects of the variety-dependent $\mathrm{S} / \mathrm{R}$ ratios on the intumescence incidence rates were investigated under conditions of high humidity, and high soil moisture content. The changes in water potential in three tomato varieties with different intumescence incidence rates were recorded when the relative humidity, and soil moisture content were abruptly changed to low or high conditions.

\section{MATERIALS AND METHODS}

\section{Experimental tomato varieties}

Twelve tomato varieties were used in the present study: 'House Momotaro', 'CF House Momotaro', 'CF Momotaro Haruka', 'Momotaro Peace', and 'Momotaro
Hope' (Takii Seed Co., Ltd., Kyoto, Japan); 'Sunroad', 'Reiyo', 'Reika', and 'Reishun' (Sakata Seed Co., Ltd., Kanagawa, Japan); 'TY Misora 86' (Mikado Kyowa Seed Co., Ltd., Chiba, Japan); 'Shonan Pomoron Red', and 'Shonan Pomoron Gold' (grown in Kanagawa Prefecture, Hoya et al., 2013; Yasui et al., 2018). These varieties are extensively cultivated in Japan, especially in Kanagawa Prefecture.

\section{Shoot:root $(S / R)$ ratio measurement}

Twenty-four seeds of the test varieties were sown in 128 -well cell trays filled with commercial vegetable seedling soil composed of peat moss and vermiculite ('Nae-shokunin', Kaneko Seeds Co., Ltd., Gunma, Japan) and grown for 16 days in a "Nae-Terrace" closed seedling-production system (Mitsubishi Chemical Agri Dream Co., Ltd., Tokyo, Japan). The system temperature was set to a constant $30^{\circ} \mathrm{C}$ during the first 4 days after sowing to $30 / 25^{\circ} \mathrm{C}$ (light/dark) at $5^{-9}$ days after sowing, and then to $28 / 23^{\circ} \mathrm{C}$ (light/dark) for the remainder of the experimental period. Seedlings were grown under natural relative humidity conditions and irrigated once a day for 10 minutes with a nutrient solution (Otsuka-A formula, Electrical Conductivity $(E C)=1.0 \mathrm{dS} \mathrm{m}^{-1}$; by OAT Agrio Co., Ltd., Tokyo, Japan) by using an automatic bottom-watering system attached to the seedling-production system. At sampling, four or five seedlings were collected and separated into shoots and roots and then oven-dried $\left(60^{\circ} \mathrm{C}\right)$ to a constant mass and weighed. None of the seedlings showed any symptoms of intumescence at sampling.

\section{Severity of intumescence measurement}

Eight seeds of each variety were sown with three replicates (i.e., $n=24$ seeds sown per variety). Seeds were germinated and grown in a closed seedling production system, "Nae-Terrace," as described previously. Seedlings were irrigated once a day in the closed seedling production system. All the seeds that germinated were included in the survey. Seedlings grown for 14 days were placed in a controlled environment chamber set at a constant temperature of $30^{\circ} \mathrm{C}$, a constant relative humidity of $90 \%, 600 \mathrm{ppm}$ $\mathrm{CO}_{2}, 450 \mu \mathrm{mol} \mathrm{m} \mathrm{s}^{-2}$ photon flux density, and a 12 


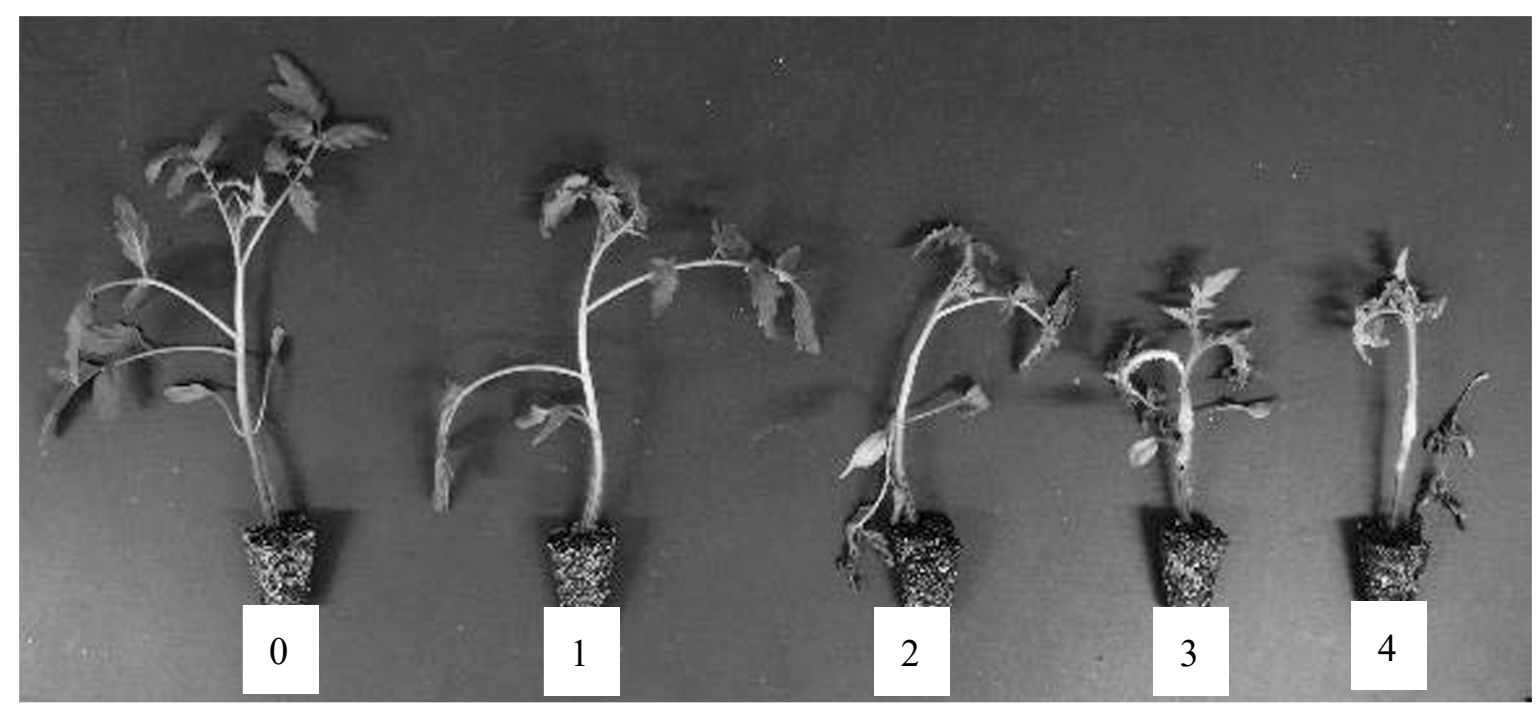

Fig. 2 Representative seedlings of the indices used to calculate intumescence severity in tomato seedlings. Severity $=100 \times$ $\Sigma$ (number of strains by severity $\times$ index $) /(4 \times$ number of investigated strains). Index 0 : No occurrence; $1:$ symptoms observed in $\leq 50 \%$ of the leaf area; 2 : symptoms observed in $\geq 50 \%$ of the leaf area, but no leaf abscission; 3 : intumescence observed in $\geq 50 \%$ of the leaf area and $\leq 50 \%$ leaf abscission; 4 : intumescence observed in $\geq 50 \%$ of the leaf area and $\geq 50 \%$ leaf abscission.

hours/12 hours light/dark regime (LPH-411SPC, Nippon Medical \& Chemical Instruments Co., Ltd., Tokyo, Japan). None of the seedlings showed any symptoms of intumescence prior to the start of the experiment. Seedlings were irrigated via a continuous, bottom-water supply in the controlled environment chamber. The number of plants affected by intumescence and the severity of intumescence injury were recorded on days 3, 6, and 9 after treatment initiation. The degree of intumescence in each individual plant was measured and intumescence severity was determined using the following scale: $0=$ no occurrence; $1=$ symptoms observed in $\leq 50 \%$ of the leaf area; $2=$ symptoms observed in $\geq 50 \%$ of the leaf area, but no leaf abscission; $3=$ intumescence observed in $\geq 50 \%$ of the leaf area and $\leq 50 \%$ leaf abscission; $4=$ intumescence observed in $\geq 50 \%$ of the leaf area and $\geq 50 \%$ leaf abscission (Fig. 2).

Measurement of xylem pressure potential

Seedlings purchased from Berg Earth Co., Ltd. were grown for 21 days in the closed seedling production system, "Nae-Terrace", as described previously. The test varieties used were 'Momotaro Peace', which exhibited the highest intumescence incidence in the experiment to investigate the intumescence rate; 'CF House Momotaro', which showed a moderate incidence rate; and 'Reiyo', which showed the lowest incidence rate. None of the seedlings showed any symptoms of intumescence prior to the start of the experiment. The experiment was performed inside a controlled environment chamber (LPH-411PFQDT-SP, Nippon Medical \& Chemical Instruments Co., Ltd., Tokyo, Japan) set at a constant temperature of $30^{\circ} \mathrm{C}$, a constant relative humidity of $50 \%$, ambient $\mathrm{CO}_{2}$ concentration (no control), and a photon flux density of $640 \mu \mathrm{mol} \mathrm{m} \mathrm{m}^{-2} \mathrm{~s}^{-1}$. Seedlings were maintained under these conditions without irrigation for 5 hours. The relative humidity was then changed to $90 \%$ and continuous bottom watering was provided simultaneously. As a practical, fast, and easy method to estimate plant water status, the pressure chamber method (Waring and Cleary, 1967; Araki and Gotoo, 1987) was used to measure xylem pressure potential by cutting the stalks of the sampled seedlings at ground level with a box cutter knife and setting the entire shoot of each seedling on the xylem pressure potential measuring device (600D, PMS Instrument Co., Ltd., Oregon, USA). Five seedlings of each variety were sampled $0,1.5,3.5,6.5$, and 8.5 hours after being placed in the controlled environment chamber.

According to Barrs et al. (1970), the water potential of tomato leaves is the same as the xylem pressure potential; thus, any change in the shoot water potential would reflect variations in the xylem pressure potential, as examined in the present study. After measuring the xylem pressure potential in another set of seedlings grown under the same conditions, the seedlings were left inside the controlled environment chamber for two days without changing the settings, and the rate of intumescence in each variety was measured one and two days later.

\section{Statistical analysis}

The data of weight of shoot and root were analyzed using a one-way analysis of variance (ANOVA), and the differences among means were analyzed using the TukeyKramer multiple comparison test. All data on the rate of incidence and the severity of intumescence injury were arcsine transformed and analyzed using a one-way ANOVA. Multiple comparisons of the means were conducted using the Tukey-Kramer method. The data of xylem pressure potential were arcsine transformed, analyzed using a oneway ANOVA, and the differences among means were analyzed using the Tukey-Kramer multiple comparison test. All the analyses were conducted using Excel add-in software Statcel2 (OMS Publishing Co., Ltd., Tokyo, Japan). 


\section{Y. MIYAMA ET AL.}

\section{RESULTS}

Effect of the $S / R$ ratio on the severity of intumescence injury

The shoot and root dry matter weights and $\mathrm{S} / \mathrm{R}$ ratios are shown in Table 1. 'TY Misora 86' had the highest and 'Sunroad' had the lowest shoot and root dry weights. 'Reiyo' had the smallest S/R ratio, followed by 'Shonan Pomoron Red', and 'TY Misora 86', whereas 'Momotaro Peace' had the largest S/R ratio, followed by 'Reishun', and 'House Momotaro'.
Table 2 shows the intumescence injury severity of each variety. Intumescence occurred in six of the twelve tested varieties on day three after placement in the controlled environment chamber and was observed in all varieties on day nine. Intumescence was confirmed in all seedlings of all varieties, except for 'Reiyo'. The severity of intumescence injury was lowest in 'Reiyo', followed by 'Shonan Pomoron Gold', and 'Sunroad'. However, 'Momotaro Peace', 'CF Momotaro Haruka', and 'Reika' showed high severity of intumescence injury $(\geq 90.0)$. Figure 3 illustrates the effect of the $\mathrm{S} / \mathrm{R}$ ratio on the severity of intumescence injury nine days after placement in the con-

Table 1 Shoot and root dry weights (DW) and shoot/root (S/R) ratios (DW basis) of experimental tomato varieties.

\begin{tabular}{llcc}
\hline \multicolumn{1}{c}{ Variety } & $\begin{array}{c}\text { Shoot DW } \\
(\mathrm{mg})\end{array}$ & $\begin{array}{c}\text { Root DW } \\
(\mathrm{mg})\end{array}$ & $\begin{array}{c}\text { Shoot:root DW } \\
\text { ratio (S/R) }\end{array}$ \\
\hline House Momotaro & $124.2 \pm 36.1 \mathrm{bc}^{\mathrm{z}}$ & $12.3 \pm 3.9 \mathrm{bc}$ & $10.1 \pm 1.0 \mathrm{abc}$ \\
CF House Momotaro & $155.3 \pm 23.1 \mathrm{abc}$ & $17.0 \pm 2.1 \mathrm{bc}$ & $9.1 \pm 0.6 \mathrm{bcd}$ \\
CF Momotaro Haruka & $151.9 \pm 33.0 \mathrm{abc}$ & $16.3 \pm 4.1 \mathrm{abc}$ & $9.3 \pm 0.4 \mathrm{abcd}$ \\
Momotaro Peace & $137.8 \pm 52.9 \mathrm{abc}$ & $12.7 \pm 5.6 \mathrm{bc}$ & $10.8 \pm 1.0 \mathrm{a}$ \\
Momotaro Hope & $167.3 \pm 62.1 \mathrm{abc}$ & $19.9 \pm 8.1 \mathrm{abc}$ & $8.4 \pm 0.9 \mathrm{cde}$ \\
Sunroad & $115.9 \pm 25.4 \mathrm{c}$ & $12.0 \pm 2.3 \mathrm{c}$ & $9.6 \pm 1.1 \mathrm{abcd}$ \\
Reiyo & $148.4 \pm 20.0 \mathrm{abc}$ & $20.2 \pm 2.8 \mathrm{abc}$ & $7.4 \pm 0.2 \mathrm{e}$ \\
Reika & $198.7 \pm 34.0 \mathrm{ab}$ & $21.3 \pm 3.5 \mathrm{ab}$ & $9.3 \pm 0.9 \mathrm{abcd}$ \\
Reishun & $136.5 \pm 33.8 \mathrm{abc}$ & $13.2 \pm 4.3 \mathrm{bc}$ & $10.3 \pm 1.2 \mathrm{abc}$ \\
TY Misora86 & $208.3 \pm 16.9 \mathrm{a}$ & $25.8 \pm 2.7 \mathrm{a}$ & $8.1 \pm 0.6 \mathrm{de}$ \\
Shonan Pomoron Red & $137.1 \pm 44.9 \mathrm{abc}$ & $17.2 \pm 5.3 \mathrm{abc}$ & $8.0 \pm 0.8 \mathrm{de}$ \\
Shonan Pomoron Gold & $144.4 \pm 29.3 \mathrm{abc}$ & $17.1 \pm 3.2 \mathrm{abc}$ & $8.5 \pm 0.9 \mathrm{cde}$ \\
\hline
\end{tabular}

${ }^{z}$ Mean \pm SD $(n=4$ or 5 ). Means within columns followed by different lowercase letters are different at the $5 \%$ significance level, based on the Tukey-Kramer test.

Table 2 Difference in the severity ${ }^{\mathrm{Z}}$ of intumescence among tomato varieties under conditions of $90 \%$ relative humidity and sub-irrigation after 3,6 , and 9 days.

\begin{tabular}{lccc}
\hline & \multicolumn{3}{c}{ Days after treatment } \\
\hline Variety & After 3 days & After 6 days & After 9 days \\
\hline House Momotaro & $0.0 \pm 0.0 \mathrm{~d}^{\mathrm{y}}$ & $16.2 \pm 3.0 \mathrm{de}$ & $79.2 \pm 9.2 \mathrm{bc}$ \\
CF House Momotaro & $1.0 \pm 1.0 \mathrm{~d}$ & $19.8 \pm 8.5 \mathrm{de}$ & $65.3 \pm 5.0 \mathrm{~cd}$ \\
CF Momotaro Haruka & $13.5 \pm 3.8 \mathrm{~b}$ & $42.7 \pm 5.5 \mathrm{~cd}$ & $95.8 \pm 2.1 \mathrm{ab}$ \\
Momotaro Peace & $32.3 \pm 2.8 \mathrm{a}$ & $100.0 \pm 0.0 \mathrm{a}$ & $100.0 \pm 0.0 \mathrm{a}$ \\
Momotaro Hope & $0.0 \pm 0.0 \mathrm{~d}$ & $2.1 \pm 2.1 \mathrm{e}$ & $52.4 \pm 4.3 \mathrm{~cd}$ \\
Sunroad & $0.0 \pm 0.0 \mathrm{~d}$ & $0.0 \pm 0.0 \mathrm{e}$ & $53.3 \pm 11.7 \mathrm{~cd}$ \\
Reiyo & $0.0 \pm 0.0 \mathrm{~d}$ & $0.0 \pm 0.0 \mathrm{e}$ & $16.7 \pm 4.2 \mathrm{~d}$ \\
Reika & $26.0 \pm 2.8 \mathrm{a}$ & $70.8 \pm 2.8 \mathrm{~b}$ & $95.8 \pm 2.8 \mathrm{ab}$ \\
Reishun & $4.2 \pm 1.0 \mathrm{~cd}$ & $52.1 \pm 12.7 \mathrm{bc}$ & $59.4 \pm 13.6 \mathrm{~cd}$ \\
TY Misora 86 & $11.5 \pm 1.0 \mathrm{bc}$ & $25.0 \pm 0.0 \mathrm{de}$ & $77.1 \pm 8.1 \mathrm{~b}$ \\
Shonan Pomoron Red & $0.0 \pm 0.0 \mathrm{~d}$ & $21.9 \pm 1.8 \mathrm{de}$ & $51.3 \pm 10.3 \mathrm{~cd}$ \\
Shonan Pomoron Gold & $0.0 \pm 0.0 \mathrm{~d}$ & $0.0 \pm 0.0 \mathrm{e}$ & $33.3 \pm 8.3 \mathrm{~d}$ \\
\hline
\end{tabular}

$\mathrm{z}$ Severity $=100 \times \Sigma($ number of seedlings by severity $\times$ index $) /(4 \times$ number of investigated seedlings). Index 0: No occurrence

1: Symptoms observed in $\leq 50 \%$ of the leaf area

2: Symptoms observed in $\geq 50 \%$ of the leaf area, but no leaf abscission

3: Intumescence observed in $\geq 50 \%$ of the leaf area and $\leq 50 \%$ leaf abscission

4: Intumescence observed in $\geq 50 \%$ of the leaf area and $\geq 50 \%$ leaf abscission

${ }^{\mathrm{y}}$ Mean \pm standard error (SE) (2-8 seedlings per replication; 3 replications).

Statistical processing was performed after arcsine transformation. Means within columns followed by different lowercase letters are different at the $5 \%$ significance level, based on the Tukey-Kramer test. 


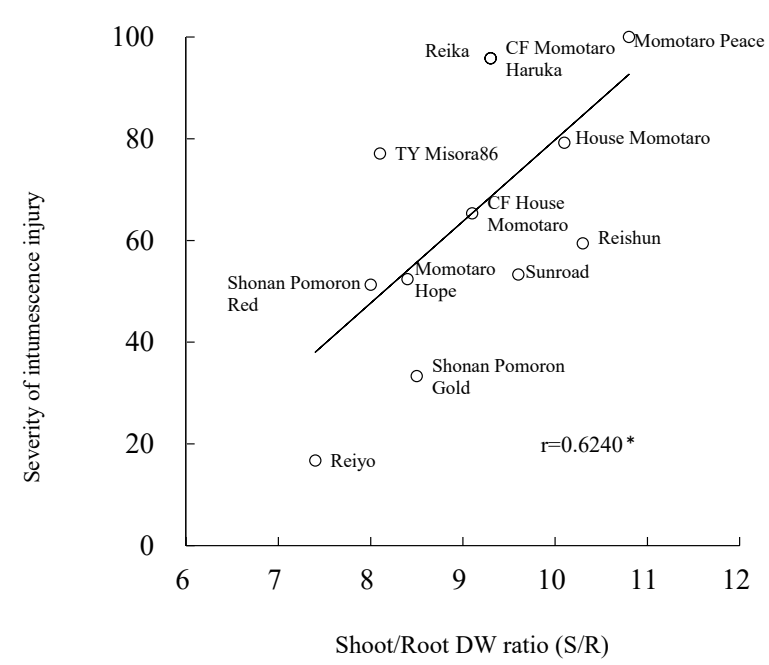

Fig. 3 Effect of the shoot/root ratio (S/R) [on a dry weight (DW) basis] on the severity of intumescence injury on day nine after treatment initiation. $* 5 \%$ is regarded as significant.

trolled environment chamber. A positive correlation was observed between the S/R ratio and the onset of intumescence after treatment initiation $(r=0.6240,5 \%$ significance level). Varieties with lower $\mathrm{S} / \mathrm{R}$ ratios showed less severe intumescence injury.

Variety-based changes in xylem pressure potential under changing water conditions

The changes in the xylem pressure potential after a change in the water environment were investigated for varieties 'Momotaro Peace', 'CF House Momotaro', and 'Reiyo'. These varieties were found to be highly susceptible, moderately susceptible, and resistant to intumescence, respectively. Figure 4 shows the changes in xylem pressure potential and soil moisture content measurements. The xylem pressure potential decreased in the following order under $50 \%$ relative humidity and without irrigation: 'Momotaro Peace' < 'CF House Momotaro' < 'Reiyo'. However, the xylem pressure potential increased rapidly in all three varieties under $90 \%$ relative humidity and bottom watering conditions only 5 hours after the initiation of the experiment. In summary, the shoot xylem-pressure potential decreased to a great extent in the seedlings of varieties that showed severe intumescence injury, but the subsequent recovery of xylem pressure potential under conditions of high humidity and bottom watering implied a high rate of increase. As expected, soil moisture content decreased without watering but increased sharply after watering. No significant differences in the soil moisture content were observed for any of the three varieties at all measuring times, and the plant water content did not change significantly during the period of xylem pressure potential measurement.

The severity of intumescence injury rate on one day after treatment was $0 \%$ in 'Reiyo', $8.1 \%$ in 'CF House Momotaro', and $76.6 \%$ in 'Momotaro Peace'. Significant differences in the intumescence rates were observed between 'Reiyo' and 'Momotaro Peace', and between 'CF House Momotaro' and 'Momotaro Peace' at the 5\% level

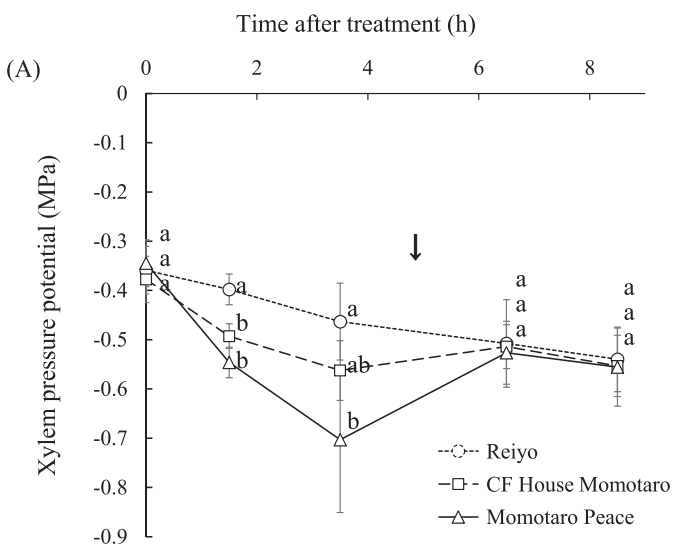

(B)

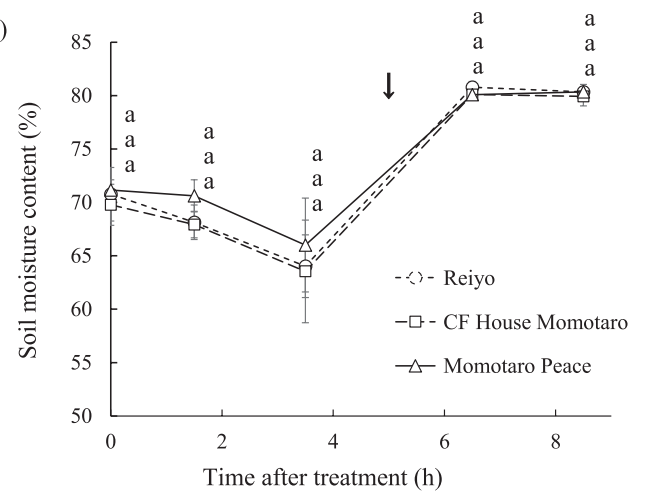

Fig. 4 Changes in the xylem pressure potential (A) and soil moisture content (B) of tomato seedlings. At 5 hours after treatment initiation $(\downarrow)$, seedlings were sub-irrigated, and the relative humidity was changed from $50 \%$ to $90 \%$. Error bars indicate standard deviation. Means within columns followed by different lowercase letters are different at the $5 \%$ significance level, based on the Tukey-Kramer test ( $n=4$ or 5$)$.

of significance, based on the Tukey-Kramer multiple comparison test. On day two, the severity of intumescence injury was $0.8 \%$ in 'Reiyo', $19.4 \%$ in 'CF House Momotaro', and $100 \%$ in 'Momotaro Peace'. The differences among the varieties were significant at the $5 \%$ level of significance, based on the Tukey-Kramer multiple comparison test.

\section{DISCUSSION}

In this study, there was a large difference in the intumescence injury among the twelve varieties surveyed. Under the experimental conditions used in the present study, the difference in the severity of intumescence injury among the tested varieties was closely related to their $S / R$ ratio, where varieties with higher $\mathrm{S} / \mathrm{R}$ ratios were more susceptible to intumescence. Assuming that no significant differences among varieties were present in terms of the water transpired per unit shoot weight or in the rate of water absorption per unit root volume, the varieties that showed large $\mathrm{S} / \mathrm{R}$ ratios would presumably experience a greater water deficit under dry conditions than varieties with lower $S / R$ ratios. In the present study, the change in plant xylem pressure potential was measured in three varie- 


\section{Y. MIYAMA ET AL.}

ties, 'Reiyo', 'CF House Momotaro', and 'Momotaro Peace', and the severity of intumescence injury was found to be greater in the varieties with large $S / R$ ratios, and in varieties that experienced greater decreases in xylem pressure potential under dry conditions. Furthermore, no differences in plant xylem pressure potential were observed among varieties after shifting from the dry to the wet conditions. Thus, the extent of the increase in plant xylem pressure potential after the shift to the wet condition was greater in the varieties in which the xylem pressure potential reached the lowest values under the dry condition, i.e., 'Momotaro Peace' < 'CF House Momotaro' < 'Reiyo'. Given these results, if ambient relative humidity and soil moisture increase suddenly when xylem pressure potential is low, and water absorption temporarily exceeds the transpiration rate, then cell rupture will likely occur, i.e., when soil and atmospheric xylem pressure potential rise rapidly, the xylem pressure potential of the plant also changes rapidly, and varieties that experience a large increase may be more prone to intumescence. This is thought to be related to the fact that the intumescence injury is more likely to occur in varieties with a higher $\mathrm{S} / \mathrm{R}$ ratio.

Intumescence is reportedly associated with high ambient humidity (Metwally et al., 1970; Eisa and Dobrenz, 1971; Misu et al., 2018). However, high and low humidity levels do not seem to affect the occurrence of intumescence (Lang and Tibbitts, 1983). Thus, the effect of relative humidity or ambient-air water potential on the occurrence of intumescence remains controversial. The experiments in the present study were performed under conditions in which there was a sudden increase in both the ambient relative humidity and soil moisture content, which induced intumescence.

There are differences among tomato varieties in terms of the effect of drought stress, and varieties with a lower drought tolerance show a greater decrease in water potential under drought stress than varieties with greater drought tolerance (Rahman et al., 1998, 1999). Based on these findings, drought-tolerant varieties are thought to be more capable of resisting changes in the surrounding water environment. Therefore, varieties with a greater drought tolerance may be expected to be less susceptible to intumescence; however, this notion requires further investigation. Sato et al. (2003) reported that differences in the leaf and root structure, and in the ability of plants to regulate water potential in response to low water availability, explained the differences in the drought stress responses among pepper varieties (Capsicum annuиm L.). In the present study, the balance between the shoot and dry root weights was assumed to represent the balance between transpiration and water absorption rates.

Here, we examined the differences in intumescence incidence among tomato seedlings in a changing water environment; however, because a single variety can exhibit different $\mathrm{S} / \mathrm{R}$ ratios under different water management schemes, the incidence of intumescence may also vary. Furthermore, changes in the water environment may lead to different intumescence incidence rates, not only in seedlings but also in mature tomato plants grown in green- houses. Therefore, further investigations are needed to develop optimal strategies for the effective control of the water environment to prevent intumescence onset.

\section{ACKNOWLEDGEMENTS}

We are grateful to Mr. Tsutomu Takahashi, Mr. Hiroyuki Kikuchi, Professor Nobuhiro Matsuoka of Chiba University, and Professor Toshitaka Uchino of Kyushu University for their kind advice regarding the experiments. We also thank the staff of Kanagawa Agricultural Technology Center, including Shigeki Henmi, who assisted with the $\mathrm{S} / \mathrm{R}$ ratio measurements. Parts of this study were carried out at Kanagawa Agricultural Technology Center, where the first author was previously employed. This study was funded in part by the Grants-in-Aid for Scientific Research (Number JP 19K06013). The authors declare there are no conflicts of interest.

\section{REFERENCES}

Araki, Y. 1993. Effects of environmental conditions on plant water status in tomato. (in Japanese with English abstract) J. Jpn. Soc. Hortic. Sci. 61: 827-837.

Araki, Y., Gotoo, Y. 1987. Application of the pressure chamber method to tomato leaflets for determination of water potential. (in Japanese with English abstract) J. Jpn. Soc. Hortic. Sci. 56: $328-333$.

Balge, R. J., Struckmeyer, B. E., Beck, G. E. 1969. Occurrence, severity, and nature of oedema in Pelargonium hortorum Ait. J. Am. Soc. Hortic. Sci. 94: 181-183.

Barrs, H. D., Freeman, B., Blackwell, J., Ceccato, R. D. 1970. Comparisons of leaf water potential and xylem water potential in tomato plants. Aust. J. Biol. Sci. 23: 485-487.

Craver, J. K., Miller, C. T., Williams, K. A., Boyle, D. L. 2014. Characterization and comparison of lesions on ornamental sweetpotato 'Blackie', tomato 'Maxifort', interspecific geranium 'Caliente Coral', and bat-faced cuphea 'Tiny Mice'. J. Am. Soc. Hortic. Sci. 139: 603-615.

Eguchi, T., Hernández, R., Kubota, C. 2016. Far-red and blue light synergistically mitigate intumescence injury of tomato plants grown under ultraviolet-deficit light environment. HortScience 51: 712-719.

Eisa, H. M., Dobrenz, A. K. 1971. Morphological and anatomical aspects of oedema in eggplants (Solanum melongena L.). J. Am. Soc. Hortic. Sci. 96: 766-769.

Fusao, K. 2003. Effects of water potential in soil, weather, and period of adding water stress on the water potential, growth, yield, and quality of fruits of tomato (Lycopersicon esculentum) plant. (in Japanese) Bull. Hiroshima Agric. Res. Cent. 75: $1-7$.

Hoya, A., Kitaura, T., Yoshida, M., Soga, A., Kita, N. 2013. New hybrid tomato cultivars, 'Shonan Pomoron Red' and 'Shonan Pomoron Gold,' suitable for both fresh salad and cooking. (in Japanese with English abstract) Bull. Kanagawa Agric. Res. Inst. 157: 1-6.

Kramer, P. J., Boyer, J. S. 1995 . Water Relations of Plants and Soils. Academic Press, London, p 16-41.

Lang, S. P., Struckmeyer, B. E., Tibbitts, T. W. 1983. Morphology and anatomy of intumescence development on tomato plants. J. Am. Soc. Hortic. Sci. 108: 266-271.

Lang, S. P., Tibbitts, T. W. 1983. Factors controlling intumescence development on tomato plants. J. Am. Soc. Hortic. Sci. 108: $93-98$. 


\section{INTUMESCENCE IN TOMATOES}

Metwally, A. W., Beck, G. E., Struckmeyer, B. E. 1970. The role of water and cultural practices on oedema of Pelargonium hortorum Ait. J. Am. Soc. Hortic. Sci. 95: 808-813.

Misu, H., Mori, M., Okumura, S., Kanazawa, S., Ikeguchi, N., Nakai, R. 2018. High-quality tomato seedling production system using artificial light. SEI Tech. Rev. 86: 119-124.

Moles T. M., Mariotti, L., De Pedro, L. F., Guglielminetti, L., Picciarelli, P., Scartazza, A. 2018. Drought induced changes of leaf-to-root relationships in two tomato genotypes. Plant Physiol. Biochem. 128: 24-31.

Ozawa, C., Tonooka, C., Kiriiwa, Y., Suzuki, K. 2018. Cultivar difference in occurrence of edema in tomato. (in Japanese) Hortic. Res. (Jpn.) 17: 436.

Petitte, J. M., Ormrod, D. P. $1986 . \quad$ Factors affecting intumescence development on potato leaves. HortScience 21: 493-495.

Pinkard, E., Gill, W., Mohammed, C. 2006. Physiology and anatomy of lenticel-like structures on leaves of Eucalyptus nitens and Eucalyptus globulus seedlings. Tree Physiol. 26 989-999.

Rahman, S. M. L., Nawata, E., Sakuratani, T. 1998. Evaluation of drought tolerance of tomato cultivars. Jpn. J. Trop. Agric. 42: 29-38.

Rahman, S. M. L., Nawata, E., Sakuratani, T. 1999. Effect of water stress on growth, yield, and eco-physiological responses of four tomato (Lycopersicon esculentum Mill.) cultivars. J. Jpn. Soc. Hortic. Sci. 68: 499-504.

Sato, S., Moreshet, S. M., Takagaki, Y., Shinohara, A., Ito, T.
2003. Effects of drought stress on sap flow, stomatal conductance, and leaf water potential of pepper cultivars (Capsicum annuum L.). Jpn. J. Trop. Agric. 47: 61-69.

Suzuki, K., Ozawa, C., Kiriiwa, Y. 2020. Morphological study on the incidence of intumescence injury in tomato plant leaves. Hortic. J. 89: 593-601.

Torrecillas, A., Guillaume, C., Alarcón, J. J., Ruíz-Sánchez, M. C. 1995. Water relations of two tomato species under water stress and recovery. Plant Sci. 105: 169-176.

Waring, R. H., Cleary, B. D. $1967 . \quad$ Plant moisture stress: evaluation by pressure bomb. Science 155: 1248-1254.

Wetzstein, H. Y., Frett, J. J. 1984. Light and scanning electron microscopy of intumescences on tissue-cultured, sweetpotato leaves. J. Am. Soc. Hortic. Sci. 109: 280-283.

Wu, Q., Park, S., Kirkham, M. B., Williams, K. A. 2017. Transcriptome analysis reveals potential mechanisms for inhibition of intumescence development by UV radiation in tomato. Environ. Exp. Bot. 134: 130-140.

Yasui, N., Hoya, A., Fujishiro, T., Kitaura, T. 2018. Characteristics of growth and yield of tomato varieties 'Shonan Pomoron Red' and 'Shonan Pomoron Gold' across different cropping types. Bull. (in Japanese with English abstract) Kanagawa Agric. Res. Inst. 162: 1-9.

Zhang, D., Du, Q., Zhang, Z., Jiao, X., Song, X., Li, J. 2017. Vapour pressure deficit control in relation to water transport and water productivity in greenhouse tomato production during summer. Sci. Rep. 7: 43461 